\title{
Effect of selenium enrichment on metabolism of tomato (Solanum lycopersicum) fruit during post-harvest ripening.
}

Running title: Ripening and post-harvest shelf-life of Se-enriched tomato fruit

Martina Puccinelli, ${ }^{\mathrm{a}}$ Fernando Malorgio, ${ }^{\mathrm{a}, \mathrm{b}}$ Leon A.Terry, ${ }^{\mathrm{c}}$ Roberta Tosetti, ${ }^{\mathrm{c}}$ Irene Rosellini ${ }^{\mathrm{d}}$ and Beatrice Pezzarossa ${ }^{\mathrm{d} *}$

${ }^{a}$ Department of Agriculture, Food and Environment, University of Pisa, Italy

${ }^{\mathrm{b}}$ Interdepartmental Research Center "Nutraceuticals and Food for Health", University of Pisa,

Via del Borghetto 80, 56124, Pisa, Italy

${ }^{\mathrm{c}}$ Plant Science Laboratory, Cranfield University, Bedfordshire MK43 OAL, UK

${ }^{\mathrm{d}}$ Institute of Ecosystem Study, CNR, via Moruzzi 1, 56124 Pisa, Italy

\begin{abstract}
BACKGROUND: Selenium (Se) enrichment of plants seems effective in enhancing the healthrelated properties of produce, and in delaying plant senescence and fruit ripening. The current study investigated the effects of Se on tomato fruit ripening. Tomato (Solanum lycopersicum L.) plants were grown in hydroponics with different Se-enriched nutrient solutions. Se, as sodium selenate, was added at rate of $0 \mathrm{mg} \mathrm{L}^{-1}$ (control), $1 \mathrm{mg} \mathrm{L}^{-1}$, and $1.5 \mathrm{mg} \mathrm{L}^{-1}$.

RESULTS: Selenium was absorbed by roots and translocated to leaves and fruit. Se enrichment did not significantly affect the qualitative parameters of fruit at commercial harvest, instead it delayed ripening by affecting specific ripening-related processes (respiration, ethylene production, color evolution) during postharvest. In the current experiment $100 \mathrm{~g}$ of tomato hydroponically grown with a $1.5 \mathrm{mg} \mathrm{Se} \mathrm{L}^{-1}$ enriched solution provided a total of $23.7 \mu \mathrm{g}$ Se. Selenium recommended daily intake is $60 \mu \mathrm{g}$ for women and $70 \mu \mathrm{g}$ for men, thus the daily consumption of $100 \mathrm{~g}$ of enriched tomato would not lead to Se toxicity, but would provide a good Se diet supplementation.

CONCLUSIONS: The cultivation of tomato plants in a Se-enriched solution appeared effective in producing tomato fruit with improved performances during storage and postharvest shelf life, and also with greater potential health-promoting properties.
\end{abstract}

Keywords: hydroponics; Se-enriched fruit; storage; shelf-life

This article has been accepted for publication and undergone full peer review but has not been through the copyediting, typesetting, pagination and proofreading process, which may lead to differences between this version and the Version of Record.

Please cite this article as doi: 10.1002/jsfa.9455

This article is protected by copyright. All rights reserved. 


\section{INTRODUCTION}

Mineral nutrition is one of the main factors affecting several aspects of fruit and vegetable production: phytochemical content, ${ }^{1}$ growth and development, susceptibility to biotic and abiotic stresses, pre- and postharvest performances. ${ }^{2}$ The effects of essential micronutrients on fruit quality have been widely described, ${ }^{3,4}$ whereas only few studies have reported the effects of non-essential micronutrients on the qualitative characteristics of fruit. ${ }^{5}$

Selenium (Se) is classified as a non-essential micronutrient for plants, but despite this, Se seems to delay plant senescence and fruit ripening, and therefore to decrease postharvest losses. These benefits are likely due to its ability in increasing antioxidant defenses as previously described. ${ }^{6-8}$ In particular, Xue and colleagues ${ }^{9}$ reported that selenium supplementation resulted in improved gluthatione peroxidase (GPXs; EC 1.11.1.9) and superoxide dismutase (SOD; EC 1.15.1.1) activities, together with a reduced decline in tocopherol content. In tomato fruit, Se concentration is negatively correlated with the content of some reactive oxygen species (ROS), such as hydrogen peroxide and superoxide, and positively correlated with glutathione peroxidase and glutathione reductase activity. ${ }^{8,10}$ In tomato plants, treatments with Se induced positive effects on the oxidative status of fruit and delayed fruit ripening. ${ }^{11-13}$

Se has been proved to delay postharvest losses also affecting ethylene production in different produce, such as broccoli, ${ }^{14}$ tomato $^{8,12}$ and in some leafy vegetables. ${ }^{7}$ In peach and pear, foliar and fruit selenium spraying delayed the reduction of flesh firmness and the onset of fruit ripening, thus improving the fruit shelf-life. ${ }^{15}$ Se plays a crucial role in human diet and animal feed. As a component of selenoaminoacids and selenoproteins, Se has been previously considered an essential trace element, a natural antioxidant, and an effective anticarcinogenic agent. ${ }^{16,17}$ Thus, improving the dietary Se intake, without exceeding the toxic threshold, i.e. $400 \mu \mathrm{g}$ of Se per day, ${ }^{18}$ may have long-term health benefits. ${ }^{19}$ The Se-enrichment of vegetables represents a safe way to increase its intake, since the organic compounds of Se contained in plants are more bioavailable than inorganic forms. ${ }^{20}$ Vegetables grown in hydroponics can be fortified by adding Se to the nutrient solution, which allows the control of Se available for plants, avoiding hyperaccumulation. ${ }^{7,12,21}$

The present study aimed to better evaluate the efficacy of Se in delaying postharvest ripening and increasing fruit quality. The effects of different Se treatments (i.e, 0,1 and $1.5 \mathrm{mg} \mathrm{Se} \mathrm{L}^{-1}$, added to the nutrient solution as sodium selenate) on fruit quality and postharvest ripening were investigated by measuring physiological (ethylene production, respiration rate, softening, color changes), and biochemical (non-structural carbohydrates and carotenes biosynthesis, chlorophylls degradation) parameters in fruit of Se-enriched tomato plants after harvest.

This article is protected by copyright. All rights reserved. 


\section{MATERIALS AND METHODS}

\section{Plant material and experimental design}

Tomato plants (Solanum lycopersicum L. cv. Red Bunch) were grown from February to June 2016, at the Department of Agriculture, Food and Environment of the University of Pisa, Italy (lat. $43^{\circ}$ $40^{\prime} \mathrm{N}$ ). Tomato seeds were sown, on $12^{\text {th }}$ February, in 254-cell plug-trays filled with rock wool and vermiculite, and germinated in a growth chamber at $25^{\circ} \mathrm{C} .14$ days after sowing, seedlings were placed into rock wool blocks $(75 \times 75 \times 65 \mathrm{~mm})$ and transferred to a heated greenhouse. After 22 days, three rock wool blocks were placed on each rock wool slabs $(1.000 \times 150 \times 75 \mathrm{~mm})$ distributed on six benches. Thirty plants were placed on each bench.

The plants were grown vertically with a single stem at a density of three plants $\mathrm{m}^{-2}$, and pollination was done by mechanical vibration of the flower clusters. Drip irrigation was performed two times per day for the first two weeks, then four times per day till the end of the experiment, according to the growth stage of tomato plant.

Sodium selenate was added once to the nutrient solution at a rate of 0 (control), 1, and $1.5 \mathrm{mg}$ Se $\mathrm{L}^{-1}$ two weeks after transplanting (April 1). Two benches, for a total of 60 plants, were allocated to each treatment.

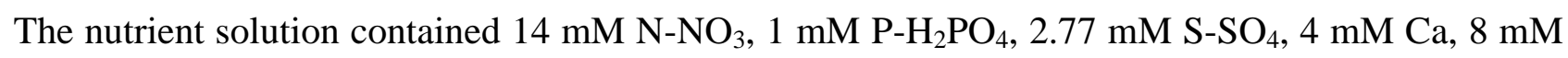
$\mathrm{K}, 1.5 \mathrm{mM} \mathrm{Mg}, 1 \mu \mathrm{M} \mathrm{Cu}, 15 \mu \mathrm{M} \mathrm{Fe}, 10 \mu \mathrm{M} \mathrm{Mn}, 1 \mu \mathrm{M}$ Mo, $5 \mu \mathrm{M} \mathrm{Zn}$. The $\mathrm{pH}$ and electrical conductivity (EC) values were 5.6 and $2.29 \mathrm{dS} \mathrm{m}^{-1}$ respectively, and were checked every 2 days. The nutrient solution was renewed every three weeks or whenever the EC was higher than $6 \mathrm{dS} \mathrm{m}^{-1}$. Climatic parameters were continuously monitored by a weather station located inside the glasshouse. The minimum, maximum and mean air temperatures were $11.2,39.4$ and $22.6{ }^{\circ} \mathrm{C}$, respectively. The relative humidity was $58.7 \%$. The daily mean and the cumulative solar radiation were 8.7 and $743 \mathrm{MJ} \mathrm{m}^{-2}$ respectively.

Two different fruit collections were performed in order to evaluate the effects of Se enrichment on tomato fruit quality (first collection) and on postharvest ripening (second collection). Ten plants per treatment were randomly selected for each harvest.

Lateral shoots and the leaves below the bottom of most-truss with ripening fruit were regularly removed.

Tomatoes were collected at commercial maturity when $50 \%$ of fruit was at the red ripe stage (i.e. 71,82 and 85 days after transplanting for the first, second and third truss, respectively) to evaluate the effects of Se treatments on tomato quality. The red fruit were analyzed for Se content. 
Qualitative analyses, oxidative stress markers analyses and antioxidant enzyme activity were carried out on fruit of the first truss of 6 plants for each treatment.

16 fruit from each of the first three trusses were harvested at colour break stage (i.e. 63,74 and 85 days after transplanting for the first, second and third truss, respectively) to evaluate the effects of Se on post-harvest ripening. Fruit of each truss from each treatment were kept separately and stored at $21^{\circ} \mathrm{C}$ and $70-75 \% \mathrm{RH}$. The following parameters were periodically measured during storage: visual evaluation of ripening, weight loss, fruit elasticity, ethylene production, respiration rate. In addition, non-structural carbohydrates and pigments contents were measured only in fruit of the first truss. Fresh (FW) and dry (DW) weights of red fruit were recorded at each harvest.

\section{Fruit analyses}

\section{Se concentration}

Total selenium concentration was determined in fruit samples oven-dried at $50{ }^{\circ} \mathrm{C}$ for 1 week. For each replicate, around 100 fruit were oven-dried and then ground in a mortar. $0.5 \mathrm{~g}$ of powder were taken for each replicate and mineralized with nitric and perchloric acids and reduced by hydrochloric acid, following Zasoski and Burau. ${ }^{22}$ The digests were analyzed by hydride generation atomic absorption spectrophotometry (Varian VGA 77). ${ }^{23}$

\section{Qualitative analysis}

For each replicate, 20 fruit were grounded and $50 \mathrm{~mL}$ of tomato purée were used to conduct the qualitative analysis. Three replicates were made for each treatment. Soluble solid content (SSC) was directly determined in the fruit juice using a digital refractometer (model 53011, Turoni, Italy). Titratable acidity was determined using $\mathrm{NaOH} 0.1 \mathrm{~N}$ to the end point of $\mathrm{pH} 8.2$ and expressed as citric acidity percentage. The taste index and maturity were calculated using the equation proposed by Navez et al. ${ }^{24}$ starting from the Brix and the titratable acidity values as indicated in Hernández Suárez et al.$^{25}$ : maturity $={ }^{\circ}$ Brix/acidity; taste index $=\left({ }^{\circ}\right.$ Brix $/ 20 \times$ acidity $)+$ acidity.

\section{Malondialdehyde (MDA) assay}

For the measurement of malondialdehyde (MDA) content, fresh fruit material was extracted with ethanol. The absorbance of reaction mixture was measured at 600, 532 and $440 \mathrm{~nm}$, and the results expressed as mmol of MDA equivalents $\mathrm{g}^{-1} \mathrm{FW}^{26}$

\section{Antioxidant Enzymes activity}

This article is protected by copyright. All rights reserved. 
For the measurement of Ascorbate Peroxidase (APX; EC 1.11.1.11), catalase (CAT; EC 1.11.1.7) and superoxide dismutase (SOD; EC 1.15.1.1) activity, $0.5 \mathrm{~g}$ of fresh material were extracted with Na-P buffer $66 \mathrm{mM}$ pH 7 + EDTA $1 \mathrm{mM}$. APX, CAT and SOD activities were evaluated as described by Lyons et al. ${ }^{27}$ measuring the extract absorbance at 290, 240 and $560 \mathrm{~nm}$, respectively. Results were corrected for the relative extinction coefficient for APX and CAT, and expressed as $\mu$ mol AsA (oxidized ascorbate) $\mathrm{g}^{-1} \mathrm{FW} \min ^{-1}$ and as $\mu \mathrm{mol} \mathrm{H}_{2} \mathrm{O}_{2} \mathrm{~g}^{-1} \mathrm{FW} \mathrm{min}{ }^{-1}$, respectively. SOD activity was expressed in unit (U). One unit is defined as the amount of SOD required to inhibit the rate of reduction of cytochrome $\mathrm{C}$ by $50 \%$ at $30{ }^{\circ} \mathrm{C}$.

For the analysis of glutathione peroxidase (GPXs; EC 1.11.1.9) activity, $1 \mathrm{~g}$ of fresh material was extracted with Na-P buffer $66 \mathrm{mM} \mathrm{pH} 7$ and centrifuged at $1100 \mathrm{~g}$ for 10 minutes. The reaction mixture containing $0.2 \mathrm{~mL}$ of extract, $0.4 \mathrm{~mL}$ of GSH $0.3 \mathrm{mM}$, and $0.2 \mathrm{~mL} \mathrm{Na-P}$ buffer $66 \mathrm{mM} \mathrm{pH}$ 7 was preincubated for 5 minutes at $25^{\circ} \mathrm{C}$. After the preincubation, the reaction was started by the addition of $0.2 \mathrm{~mL}$ of $\mathrm{H}_{2} \mathrm{O}_{2} 1.3 \mathrm{mM}$. After 10 minutes the reaction was stopped by the addition of 1 $\mathrm{mL}$ of trichloroacetic acid. Then, the samples were put in the ice for 30 minutes and, at the end, centrifuged at $100 \mathrm{~g}$ for 10 minutes. The assay mixture contained $0.24 \mathrm{~mL}$ of supernatant, $1.10 \mathrm{~mL}$ of buffer Na-P 0.32 M pH 7, $0.16 \mathrm{~mL}$ of 5,5'-dithiobis(2-nitrobenzoic acid) (DTNB) $1 \mathrm{mM}$. The absorbance of the assay mixture was measured at $412 \mathrm{~nm}$ and the results expressed as $\mu$ moli GSH g ${ }^{-}$

${ }^{1} \mathrm{FW} \mathrm{min}^{-1}$. For the calibration curve growing concentrations of glutathione (GSH) were used. ${ }^{28}$

\section{Visual evaluation}

The visual evaluation of fruit post-harvest ripening was performed 1, 4, 6, 8 and 10 days after harvest for the first truss, 1, 3, 8, 10, 12 and 15 days after harvest for the second truss, and 3, 6, 10 and 12 days after harvest for the third truss. Fruit were classified by comparing the individual color to the ripening stages reported in the "United States standards for grades of fresh tomatoes". ${ }^{29}$ The number of fruit at each ripening stage was recorded and a ranking was used to evaluate the development of fruit colour.

At each ripening stage was assigned a growing score from breakers to red fruit. ${ }^{29}$ The average ripening stage of each set of fruit was calculated according to the formula:

ripening stage $=\frac{n . f . \text { breakers } \times 2+n . f . \text { turning } \times 3+n . f . \text { pink } \times 4+n . f . \text { light red } \times 5+n . f . r e d \times 6}{n . f . \text { total }}$

\section{Weight loss}

6 fruit for each truss of each treatment were weighted at harvest, and then every 3 days during storage at $21^{\circ} \mathrm{C}$ and $70-75 \% \mathrm{RH}$ for 15 days.

This article is protected by copyright. All rights reserved. 


\section{Fruit elasticity}

A Shore durometer type A was used to measure fruit elasticity $0,4,6,8,11$ and 13 days after harvest for the first truss, $0,2,7,9,11$ and 14 days after harvest for the second truss, and 0, 3, 6, 10 and 12 days after harvest for the third truss. The durometer measures the depth of an indentation in the material created by a given force on a standardized presser foot. There are several scales of durometers, used for materials with different properties. The scale used was the ASTM D2240 type A. However, the ASTM D2240-00 testing standard calls for a total of 12 scales, depending on the intended use. Each scale results in a value between 0 and 100, with higher values indicating a harder material.

Six fruit for each truss of all treatments were pressed at the opposite sides of their equatorial axes, and results were expressed as shore hardness. Shore values are internationally defined as resistance to a $2.4 \mathrm{~mm}$ diameter plunger to penetrate an intact fruit using a Turioni Durometer. ${ }^{30}$

\section{Ethylene production and respiration rate}

Ethylene production and respiration rate were measured 0,3,5,7 and 9 days after harvest in fruit of the first truss, 0, 3, 5, 7, 9 and 11 days after harvest in the fruit of the second and third truss. During this period fruit were stored at $21^{\circ} \mathrm{C}$. Four fruit for each truss of each treatment were placed in four $85 \mathrm{~mL}$ glass tubes (Pyrex, France) and closed with holed plastic screw caps supplied with caoutchouc rubber septa. Analysis was performed according to Malorgio et al. ${ }^{7}$

\section{Non-structural carbohydrate content}

Content of non-structural carbohydrates was measured in fruit of the first truss at the red stage. Four replicates were made for each treatment. Each replicate consisted of 6 fruits. Carbohydrates were extracted from ground samples as previously reported. ${ }^{31} 150 \mathrm{mg}$ of freeze-dried tomato samples were grinded, combined and mixed with $3 \mathrm{~mL}$ of 62.5:37.5 HPLC grade methanol:water (v/v). The samples were placed in a water bath at $55^{\circ} \mathrm{C}$ and shaked for $15 \mathrm{~min}$. Thereafter, the samples were cooled, filtered through $0.2 \mu \mathrm{m}$ filter and stored at $-40^{\circ} \mathrm{C} .50 \mu \mathrm{L}$ of the extract was diluted in $1 \mathrm{~mL}$ using HPLC grade water immediately prior the analysis. Non-structural carbohydrates were quantified using a Agilent 1200 series HPLC binary pump system (Agilent, Berks., UK) coupled with either an Agilent refractive index detector (RID) G1312A. Chromatography was carried out with a Phenomenex Rezex RCM monosaccharide Ca+2 (8\%) 300x7.8 mm column fitted with a Phenomenex Carbo $\mathrm{Ca}+24 \times 3 \mathrm{~mm}$ guard column. The mobile phase was HPLC grade water (filtered through a $0.4 \mu \mathrm{m}$ filter and degassed using $\mathrm{He}$ ) at a flow rate of $0.6 \mathrm{~mL} \mathrm{~min}^{-1}$. Temperature of the optical unit in the detector was set up at $35^{\circ} \mathrm{C}$ and the column at $80^{\circ} \mathrm{C}$. The autosampler was

This article is protected by copyright. All rights reserved. 
cooled at $5^{\circ} \mathrm{C}$. The concentrations of glucose, fructose and sucrose were calculated against a calibration curve prepared with authentic standards (Sigma-Aldrich, Dorset, UK) and the results were expressed on a fresh weight basis.

\section{Pigments content}

Pigments content was measured in fruit of the first truss at the red stage. Four replicates were made for each treatment. Each replicate consisted of 6 fruit. Pigments were extracted from $100 \mathrm{mg}$ ground freeze-dried tomato fruit samples as previously reported ${ }^{32}$ and quantified using an Agilent 1200 series HPLC binary pump system (Agilent, Berks., UK) coupled with either an Diode-Array Detection (DAD). Chromatography was carried out with a reverse phase column 250x4 mm i.d., 5 $\mu \mathrm{m}$ particle size. The concentrations of lycopene, $\beta$-carotene and chlorophylls were calculated by comparison against an external calibration curve prepared with authentic standards (Sigma-Aldrich, Dorset, UK) and the results expressed on a fresh weight basis.

\section{Statistical analysis}

Data were subjected to one-way analysis of variance (ANOVA) with Se treatments as variables. The means were separated using the least significance difference (LSD) $(\mathrm{P}<0.05)$. Statistical analysis was performed using Statgraphics Plus 5.1.

\section{RESULTS AND DISCUSSION}

\section{Effects of selenium on tomato fruit quality at harvest}

The addition of Se to the nutrient solution determined a significantly dose-dependent increase of Se concentration in tomato fruit of all trusses, and the average Se concentration decreased from the first to the second and third trusses (Table 1). The fruit Se concentration was in the range of 0.94-

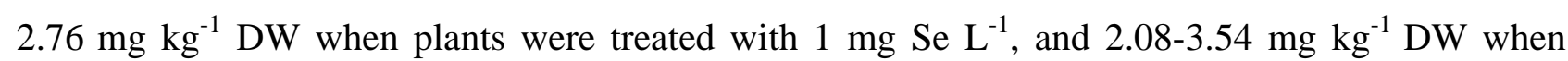

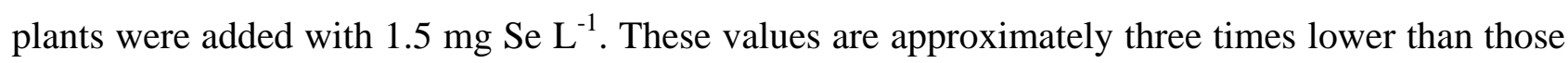
reported by Pezzarossa et al. ${ }^{12}$ which found a fruit Se concentration of $10.33 \mathrm{mg} \mathrm{kg}^{-1} \mathrm{DW}$ in plants added with $1 \mathrm{mg} \mathrm{Se} \mathrm{L}^{-1}$ as sodium selenate. These differences could be ascribed to the different growing period that in the experiment conducted by Pezzarossa et al. ${ }^{12}$ lasted from the beginning of May to the end of July, whereas in the current experiment it lasted from February to June.

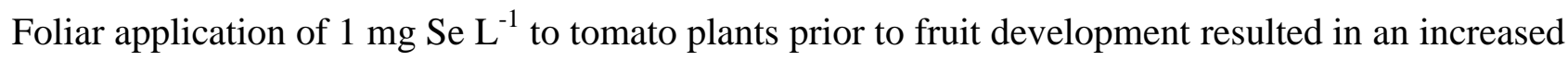
fruit selenium content of $0.6 \mathrm{mg} \mathrm{Se} \mathrm{kg}{ }^{-1}{ }^{33}$ This content is much lower compared to what reported in the current experiment suggesting that the addition of Se to the nutrient solution is likely more effective than foliar application to produce Se-enriched tomatoes.

This article is protected by copyright. All rights reserved. 
In this study the addition of selenium to the nutrient solution did not affect either plant yield or the qualitative parameters of tomato, i.e. fruit dry matter content, soluble solid content, titratable acidity, maturity and taste index (Table 2). This is in agreement with previous studies conducted on tomato plants grown under similar experimental conditions. ${ }^{11,12}$ The herein reported mean value of taste index was about 1 , indicating that the tomatoes were of good quality. Tomatoes are considered as having little taste when the taste index is lower than $0.7 .^{24}$

Ascorbate peroxidase (APX) and Catalase (CAT) activities were lower in red fruit of Se-enriched plants, 1.9 and 1.5 fold respectively, compared to control fruit. Instead, a significantly higher superoxide dismutase (SOD) activity was detected in fruit of treated plants. No differences were detected in glutathione peroxidase (GPXs) activity between control and treated plants (Table 3). This was an unexpected result that may have occurred because we analysed tomato fruit at red ripe stage. After the climacteric pick, the effect of ethylene on the oxidative status of fruit might have covered possible effects of selenium.

As far as the increase of SOD activity is concerned, plant might have perceived the increase of selenium content as a mild stress. Selenium may increase the antioxidant enzyme activity of SOD and GPXs ${ }^{10}$ and decrease various reactive oxygen species, such as $\mathrm{H}_{2} \mathrm{O}_{2}$ and superoxide, during fruit storage. ${ }^{8}$ Selenium has proven effective in increasing the oxidative status and improving the content of reduced glutathione and ascorbate of tomato fruit, thus delaying fruit ripening. ${ }^{8,13}$

\section{Effects of selenium on post-harvest ripening}

Delayed post-harvest ripening was detected in tomatoes harvested from Se-treated plants following the visual evaluation of colour development (Fig. 1). The timing of the delay in fruit ripening varied across trusses, and was more noticeable in fruit derived from the second and third truss compared to the first. In general, fruit from the first truss showed a more rapid development than fruit from the second and third truss. In fact, fruit from the first truss reached the red ripe stage earlier (7 days after harvest) compared to fruit from the second and third truss ( 9 days after harvest) (data not shown). The effect of selenium in delaying fruit post-harvest ripening, which was less evident in fruit from the first truss, may have been attenuated by the faster ripening.

The delay in fruit ripening was also confirmed by physiological parameters. Indeed, the addition of selenium to the nutrient solution was effective in postponing (2 days) the ethylene climacteric peak in fruit from all trusses (Fig. 2), and resulted in a reduced respiration rate at the climacteric peak, especially in fruit from the second and third truss (Table 4), as previously reported. ${ }^{12}$ Zhu et al. ${ }^{8}$ found that, in tomato fruit, Se suppressed the transcription of ACO1, ACS2 and ACS4, genes involved in ethylene biosynthesis, with beneficial effects in terms of prolonged commercial life.The

This article is protected by copyright. All rights reserved. 
effects of Se on the postharvest ripening were also evident by data on fruit elasticity (Fig.3). Fruit elasticity is inversely related to fruit softening. Thus, the higher values of fruit elasticity detected in treated fruit compared to control may indicate that the ripening-related loss of firmness was indeed retarded by Se. A similar result was reported by Pezzarossa et al. ${ }^{15}$ in flesh firmness of Se-enriched peaches.

Interestingly, the addition of selenium to the nutrient solution, either at 1 and $1.5 \mathrm{mg} \mathrm{Se} \mathrm{L}^{-1}$, reduced the fruit weight loss during the post-harvest ripening, especially after 12 days of storage (Fig. 4). The reduced weight loss could be related to delayed ripening or be the result of Se-induced changes in the cuticle thickness and composition. Golob et al. ${ }^{34}$ reported that wheat plants treated with selenium had thicker cuticles for both the upper and lower leaf surface. Thicker cuticles represent a barrier to the water movement from inside the tissue/organ to the external atmosphere. The lower weight loss that occurred in Se-fortified fruit compared to control may be ascribed to the increase in water retention due to the increased selenium content, as observed in olive trees ${ }^{35}$ and in Zea mays. ${ }^{36}$ This effect can be attributable not only to an increase in cuticle thickness, but also to a gene expression regulation. ${ }^{37}$

Se-enriched fruit showed also a delayed accumulation of reducing sugars (glucose and fructose) during the first week of postharvest phase (Table 5). Zhu and colleagues ${ }^{33}$ reported that Se-enriched tomato exhibited higher reducing sugars contents compared to the control fruit at harvest. However, the data of the present work investigated the evolution of ripening during postharvest. Once the ripening fruit is detached from the plant, starch breakdown represents the only source for sugars (sucrose and reducing sugars) accumulation. ${ }^{38}$ The herein reducing sugars trends in Se-enriched fruit might therefore relate with a slower (or postponed) starch degradation process due to Seinduced ripening delay. This hypothesis seemed supported also by the fruit elasticity data, which showed a quicker softening in control fruit (Fig. 3).

As above reported, the visual evaluation of fruit after harvest indicated a different colour development in Se-treated fruit (Fig. 1). Indeed, the analysis of pigments content confirmed this data: lycopene and beta-carotene accumulations were delayed in Se-treated fruit through postharvest, even if no differences were detected between Se-treated and control fruit at the end of the experiment (Table 6). In addition, chlorophylls degradation rates were slower in Se-enriched fruit compared to control (Table 6).

In the current experiment, the activity of antioxidant enzymes and the lipid peroxidation level detected in red fruit were in agreement with the delayed ripening of Se-treated fruit. During ripening, the antioxidant capacity decreases, and the lipid peroxidation consistently increases. ${ }^{39}$ The antioxidant enzymes behave differently during fruit ripening: SOD activity decreases whereas

This article is protected by copyright. All rights reserved. 
$\mathrm{CAT}^{40}$ and APX ${ }^{41}$ activity increase. Therefore, a lower lipid peroxidation, CAT and APX activities and a higher SOD activity, as detected in Se-treated fruit, may indicate a delay in fruit ripening that is not possible to discern only from the fruit color, since from the outside all fruit were at the red ripe stage. Se has an antioxidant function as a cofactor of glutathione peroxidase. In the present experiment differences in GPXs activity between treatments were not detected, probably because the Se concentration in fruit was too low. In fact, even though in plants Se has not an antioxidant function as cofactor of glutathione peroxidase as in mammalians, Castillo-Godina ${ }^{42}$ found an

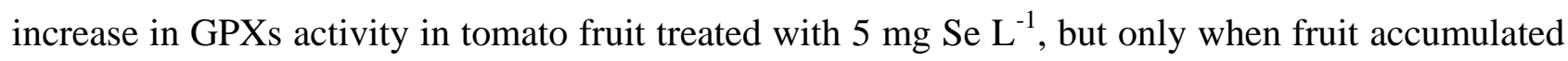
about $30 \mathrm{mg} \mathrm{Se} \mathrm{kg}^{-1}$.

The reduction in respiration rate has been already detected in tomato fruit treated with $\mathrm{Se},{ }^{8}$ and can induce a delay of fruit ripening, as found in banana by Srivastava and Dwivedi. ${ }^{43}$ A lower respiration during storage has a positive effect in improving post-harvest shelf-life of fruit.

The evaluation of tomato fruit ripening on the basis of the fruit color showed a slower color change in fruit of plants treated with Se compared to the control. This was associated with a delayed lycopene and b-carotene synthesis and chlorophylls degradation during postharvest. This could be the result of a delayed ripening, since lycopene and b-carotene concentrations increase, whereas the concentration of chlorophylls decreases during tomato ripening. ${ }^{44,45}$

As the final issue, the effect of the consumption of Se-enriched tomatoes on health was taken into consideration. Since the estimated values for Se daily intake are $60 \mu \mathrm{g}$ for women and $70 \mu \mathrm{g}$ for men, ${ }^{46}$ the consumption of $100 \mathrm{~g}$ of the Se-enriched tomatoes obtained in this experiment, with an average total Se content of $23.7 \mu \mathrm{g}$, could provide a good Se diet supplementation. The consumption of $200 \mathrm{~g}$ of fresh Se-enriched tomato could provide the recommended daily intake of Se. On the basis of the results obtained in the present experiment, and in accordance to previous studies, ${ }^{12}$ the hydroponic cultivation of tomato plants using a nutrient solution enriched in Se could represent a viable way to produce Se-enriched tomatoes.

\section{Conclusions}

The results of the present experiment support the hypothesis that Se affects specific ripening-related processes and may have a positive effect in delaying fruit ripening, thus positively affecting the postharvest shelf life of tomatoes. Selenium-treated fruit showed in fact lower respiration rate and ethylene production that slowed the postharvest ripening process. This was associated with a delayed lycopene and b-carotene synthesis, and chlorophylls degradation. The consumption of Seenriched fruit may contribute to the daily supplementation of selenium, thus improving human

This article is protected by copyright. All rights reserved. 
health. Further studies are needed to fully understand how Se affects the molecular and biochemical processes involved in fruit ripening and post-harvest storage, in order to optimize the Se-enrichment technique and the combination with post-harvest storage conditions.

\section{Acknowledgments}

Authors wish to thank Marco Landi, Department of Agriculture, Food and Environment at University of Pisa, for his helpful comments.

\section{References}

1. Jeppsson $\mathrm{N}$. The effects of fertilizer rate on vegetative growth, yield and fruit quality, with special respect to pigments, in black chokeberry (Aronia melanocarpa) cv. 'Viking'. Sci Hortic (Amsterdam). 83(2):127-37. (2000).https://doi.org/10.1016/S0304-4238(99)00070-9

2. Savvas D, Ntatsi G, Passam HC. Plant nutrition and physiological disorders in greenhouse grown tomato, pepper and eggplant. Eur J Plant Sci Biotechnol. 2:45-61. (2008).

3. Li Y, Wu J. Effects of boron and manganese on quality and antioxidative capacity in tomato. Acta Hortic. (823):115. (2009).

4. Esringü A, Turan M, Gunes A, Eşitken A, Sambo P. Boron application improves on yield and chemical composition of strawberry. Acta Agric Scand Sect B - Soil Plant Sci. 61(3):245-52. (2011).https://doi.org/10.1080/09064711003776867

5. Ríos JJ, Blasco B, Rosales MA, Sanchez-Rodriguez E, Leyva R, Cervilla LM, et al. Response of nitrogen metabolism in lettuce plants subjected to different doses and forms of selenium. J Sci Food Agric. 90(11):1914-9. (2010).https://doi.org/10.1002/jsfa.4032

6. Djanaguiraman M, Devi DD, Shanker AK, Sheeba JA, Bangarusamy U. Selenium - An antioxidative protectant in soybean during senescence. Plant Soil. 272(1-2):77-86. (2005).https://doi.org/10.1007/s11104-004-4039-1

7. Malorgio F, Diaz KE, Ferrante A, Mensuali-Sodi A, Pezzarossa B. Effects of selenium addition on minimally processed leafy vegetables grown in a floating system. J Sci Food Agric. 89(13):2243-51. (2009).https://doi.org/10.1002/jsfa.3714

8. Zhu Z, Chen Y, Shi G, Zhang X. Selenium delays tomato fruit ripening by inhibiting ethylene biosynthesis and enhancing the antioxidant defense system. Food Chem. 219:17984. (2017).https://doi.org/10.1016/j.foodchem.2016.09.138

9. Xue T, Hartikainen H, Piironen V. Antioxidative and growth-promoting effect of selenium on senescing lettuce. Plant Soil. 237(1):55-61. (2001).https://doi.org/10.1023/A:1013369804867

10. Businelli D, D'Amato R, Onofri A, Tedeschini E, Tei F. Se-enrichment of cucumber (Cucumis sativus L.), lettuce (Lactuca sativa L.) and tomato (Solanum lycopersicum L. Karst) through fortification in pre-transplanting. Sci Hortic (Amsterdam). 197:697-704. (2015).https://doi.org/10.1016/j.scienta.2015.10.039

This article is protected by copyright. All rights reserved. 
11. Pezzarossa B, Rosellini I, Malorgio F, Borghesi E, Tonutti P. Effects of selenium enrichment of tomato plants on ripe fruit metabolism and composition. Acta Hortic. (1012):247-51. (2013).https://doi.org/10.17660/ActaHortic.2013.1012.28

12. Pezzarossa B, Rosellini I, Borghesi E, Tonutti P, Malorgio F. Effects of Se-enrichment on yield, fruit composition and ripening of tomato (Solanum lycopersicum) plants grown in hydroponics. Sci Hortic (Amsterdam). 165:106-10. (2014).https://doi.org/10.1016/j.scienta.2013.10.029

13. Zhu Z, Chen Y, Zhang X, Li M. Effect of foliar treatment of sodium selenate on postharvest decay and quality of tomato fruits. Sci Hortic (Amsterdam). 198:304-10. (2016).https://doi.org/10.1016/j.scienta.2015.12.002

14. Lv J, Wu J, Zuo J, Fan L, Shi J, Gao L, et al. Effect of Se treatment on the volatile compounds in broccoli. Food Chem. 216:225-33. (2017).https://doi.org/10.1016/j.foodchem.2016.08.005

15. Pezzarossa B, Remorini D, Gentile ML, Massai R. Effects of foliar and fruit addition of sodium selenate on selenium accumulation and fruit quality. J Sci Food Agric. 92(4):781-6. (2012).https://doi.org/10.1002/jsfa.4644

16. Rotruck JT, Pope AL, Ganther HE, Swanson AB, Hafeman DG, Hoekstra WG. Selenium: Biochemical Role as a Component of Glutathione Peroxidase. Science (80- ). 179(73):58890. (1973).https://doi.org/10.1126/science.179.4073.588

17. Pallud S, Lennon AM, Ramauge M, Gavaret JM, Croteau W, Pierre M, et al. Expression of the type II iodothyronine deiodinase in cultured rat astrocytes is selenium-dependent. J Biol Chem. 272(29):18104-10. (1997).https://doi.org/10.1074/JBC.272.29.18104

18. Krinsky Ni, Beecher GR, Burk RF, Chan AC, Erdman JW, Jacob RA, et al. Dietary reference intakes for vitamin C, vitamin E, selenium, and carotenoids. In: Institute of Medicine. (2000).

19. Finley JW. Increased intakes of selenium-enriched foods may benefit human health [Internet]. Vol. 87, Journal of the Science of Food and Agriculture. John Wiley \& Sons, Ltd.; p. 1620-9. (2007).https://doi.org/10.1002/jsfa.2943

20. Hartikainen H. Biogeochemistry of selenium and its impact on food chain quality and human health. J Trace Elem Med Biol. 18(4):309-18. (2005).https://doi.org/10.1016/j.jtemb.2005.02.009

21. Ferrarese M, Mahmoodi Sourestani M, Quattrini E, Schiavi M, Ferrante A. Biofortification of Spinach Plants Applying Selenium in the Nutrient Solution of Floating System. Veg Crop Res Bull. 76(1):127-36. (2012).https://doi.org/10.2478/v10032-012-0009-y

22. Zasoski RJ, Burau RG. A rapid nitric- perchloric acid digestion method for multi- element tissue analysis. Commun Soil Sci Plant Anal. 8(5):425-36.

(1977).https://doi.org/10.1080/00103627709366735

23. Huang PM, Fujii R. Selenium and Arsenic. In: Methods of Soil Analysis Part 3 Chemical Methods-SSSA Book Series no 5. Madison, Wisconsin. USA: Soil Science Society of America; (1996).

24. Navez B, Letard M, Graselly D, Jost M. Les criteres de qualite de la tomate. Infos-Ctifl. 155:41-7. (1999).

25. Hernández Suárez M, Rodríguez Rodríguez EM, Díaz Romero C. Chemical composition of tomato (Lycopersicon esculentum) from Tenerife, the Canary Islands. Food Chem.

This article is protected by copyright. All rights reserved. 
106(3):1046-56. (2008).https://doi.org/10.1016/j.foodchem.2007.07.025

26. Hodges DM, DeLong JM, Forney CF, Prange RK. Improving the thiobarbituric acidreactive-substances assay for estimating lipid peroxidation in plant tissues containing anthocyanin and other interfering compounds. Planta. 207(4):604-11.

(1999).https://doi.org/10.1007/s004250050524

27. Lyons T, Ollerenshaw JH, Barnes JD. Impacts of ozone on Plantago major: Apoplastic and symplastic antioxidant status. New Phytol. 141(2):253-63.

(1999).https://doi.org/10.1046/j.1469-8137.1999.00338.x

28. Flohé L, Günzler WA. [12] Assays of glutathione peroxidase. Methods Enzymol. 105(July):114-20. (1984).https://doi.org/10.1016/S0076-6879(84)05015-1

29. United States Department of Agricultural. United States standards for grades of fresh tomatoes. In: Tomatoes Shipping Point and Market Inspection Instructions Shipping Point and Market Inspection Instructions for Blueberries. United States Department of Agriculture Agricultural Marketing Service Fruit and Vegetable Programs Fresh Products Branch; p. 78. (2005).

30. Lippert F, Blanke MM. Effect of mechanical harvest and timing of 1-MCP application on respiration and fruit quality of European plums Prunus domestica L. Postharvest Biol Technol. 34(3):305-11. (2004).https://doi.org/10.1016/j.postharvbio.2004.05.019

31. Terry LA, Chope GA, Giné Bordonaba J. Effect of water deficit irrigation and inoculation with Botrytis cinerea on strawberry (Fragaria $x$ ananassa) fruit quality. J Agric Food Chem. 55(26):10812-9. (2007).https://doi.org/10.1021/jf072101n

32. de Las Rivas J, Abadía A, Abadía J. A New Reversed Phase-HPLC Method Resolving All Major Higher Plant Photosynthetic Pigments. Plant Physiol. 91(1):190-2. (1989).https://doi.org/10.1104/pp.91.1.190

33. Zhu Z, Zhang Y, Liu J, Chen Y, Zhang X. Exploring the effects of selenium treatment on the nutritional quality of tomato fruit. Food Chem. 252:9-15.

(2018).https://doi.org/10.1016/J.FOODCHEM.2018.01.064

34. Golob A, Kavčič J, Stibilj V, Gaberščik A, Vogel-Mikuš K, Germ M. The effect of selenium and UV radiation on leaf traits and biomass production in Triticum aestivum L. Ecotoxicol Environ Saf. 136:142-9. (2017).https://doi.org/10.1016/j.ecoenv.2016.11.007

35. Proietti P, Nasini L, Del Buono D, D’Amato R, Tedeschini E, Businelli D. Selenium protects olive (Olea europaea L.) from drought stress. Sci Hortic (Amsterdam). 164:165-71. (2013).https://doi.org/10.1016/j.scienta.2013.09.034

36. Nawaz F, Naeem M, Ashraf MY, Tahir MN, Zulfiqar B, Salahuddin M, et al. Selenium Supplementation Affects Physiological and Biochemical Processes to Improve Fodder Yield and Quality of Maize (Zea mays L.) under Water Deficit Conditions. Front Plant Sci. 7:1438. (2016).https://doi.org/10.3389/fpls.2016.01438

37. Bocchini M, D'Amato R, Ciancaleoni S, Fontanella MC, Palmerini CA, Beone GM, et al. Soil Selenium (Se) Biofortification Changes the Physiological, Biochemical and Epigenetic Responses to Water Stress in Zea mays L. by Inducing a Higher Drought Tolerance. Front Plant Sci. 9:389. (2018).https://doi.org/10.3389/fpls.2018.00389

38. Beckles DM. Factors affecting the postharvest soluble solids and sugar content of tomato (Solanum lycopersicum L.) fruit. Postharvest Biol Technol. 63(1):129-40.

(2012).https://doi.org/10.1016/j.postharvbio.2011.05.016

This article is protected by copyright. All rights reserved. 
39. Giovinazzo G, D’Amico L, Paradiso A, Bollini R, Sparvoli F, DeGara L. Antioxidant metabolite profiles in tomato fruit constitutively expressing the grapevine stilbene synthase gene. Plant Biotechnol J. 3(1):57-69. (2005).https://doi.org/10.1111/j.1467-

7652.2004.00099.x

40. Mondal K, Sharma NS, Malhotra SP, Dhawan K, Singh R. Antioxidant systems in ripening tomato fruits. Biol Plant. 48(1):49-53. (2004).https://doi.org/10.1023/B:BIOP.0000024274.43874.5b

41. Yahia EM, Soto-Zamora G, Brecht JK, Gardea A. Postharvest hot air treatment effects on the antioxidant system in stored mature-green tomatoes. Postharvest Biol Technol. 44(2):10715. (2007).https://doi.org/10.1016/j.postharvbio.2006.11.017

42. Castillo-Godina RG, Foroughbakhch-Pournavab R, Benavides-Mendoza A. Effect of selenium on elemental concentration and antioxidant enzymatic activity of tomato plants. $\mathbf{J}$ Agric Sci Technol. 18(1):233-44. (2016).

43. Srivastava MK, Dwivedi UN. Delayed ripening of banana fruit by salicylic acid. Plant Sci. 158(1-2):87-96. (2000).https://doi.org/10.1016/S0168-9452(00)00304-6

44. Fraser PD, Truesdale MR, Bird CR, Schuch W, Bramley PM. Carotenoid biosynthesis during tomato fruit development (evidence for tissue-specific gene expression). Plant Physiol. 105(1):405-13. (1994).https://doi.org/10.1104/pp.105.1.405

45. Gautier H, Diakou-Verdin V, Bénard C, Reich M, Buret M, Bourgaud F, et al. How does tomato quality (sugar, acid, and nutritional quality) vary with ripening stage, temperature, and irradiance? J Agric Food Chem. 56(4):1241-50. (2008).https://doi.org/10.1021/jf072196t

46. Kipp AP, Strohm D, Brigelius-Flohé R, Schomburg L, Bechthold A, Leschik-Bonnet E, et al. Revised reference values for selenium intake. J Trace Elem Med Biol. 32:195-9.

(2015).https://doi.org/10.1016/J.JTEMB.2015.07.005

This article is protected by copyright. All rights reserved. 

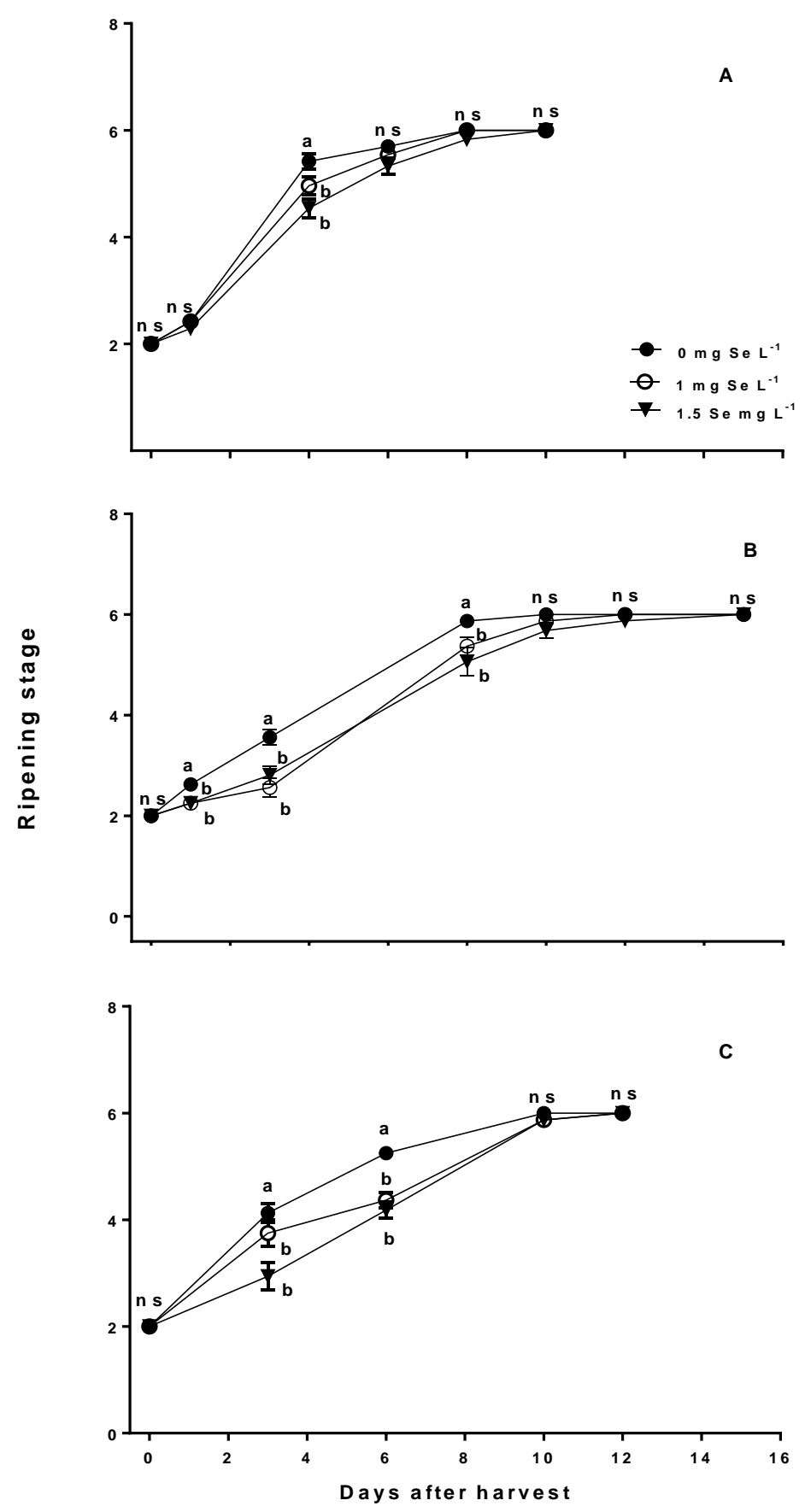

Figure 1. Post-harvest ripening process in fruit of the first (A), second (B) and third (C) truss of tomato plants (cv. Red Bunch) grown in nutrient solution supplied with 0,1 and $1.5 \mathrm{mg} \mathrm{Se} \mathrm{L}^{-1}$, on the basis of visual color appearance. Data are means $\pm S E(n=4)$. Values with the same letter are not statistically different for $\mathrm{p} \leq 0.05 \%$; ns $=$ not significant

This article is protected by copyright. All rights reserved. 

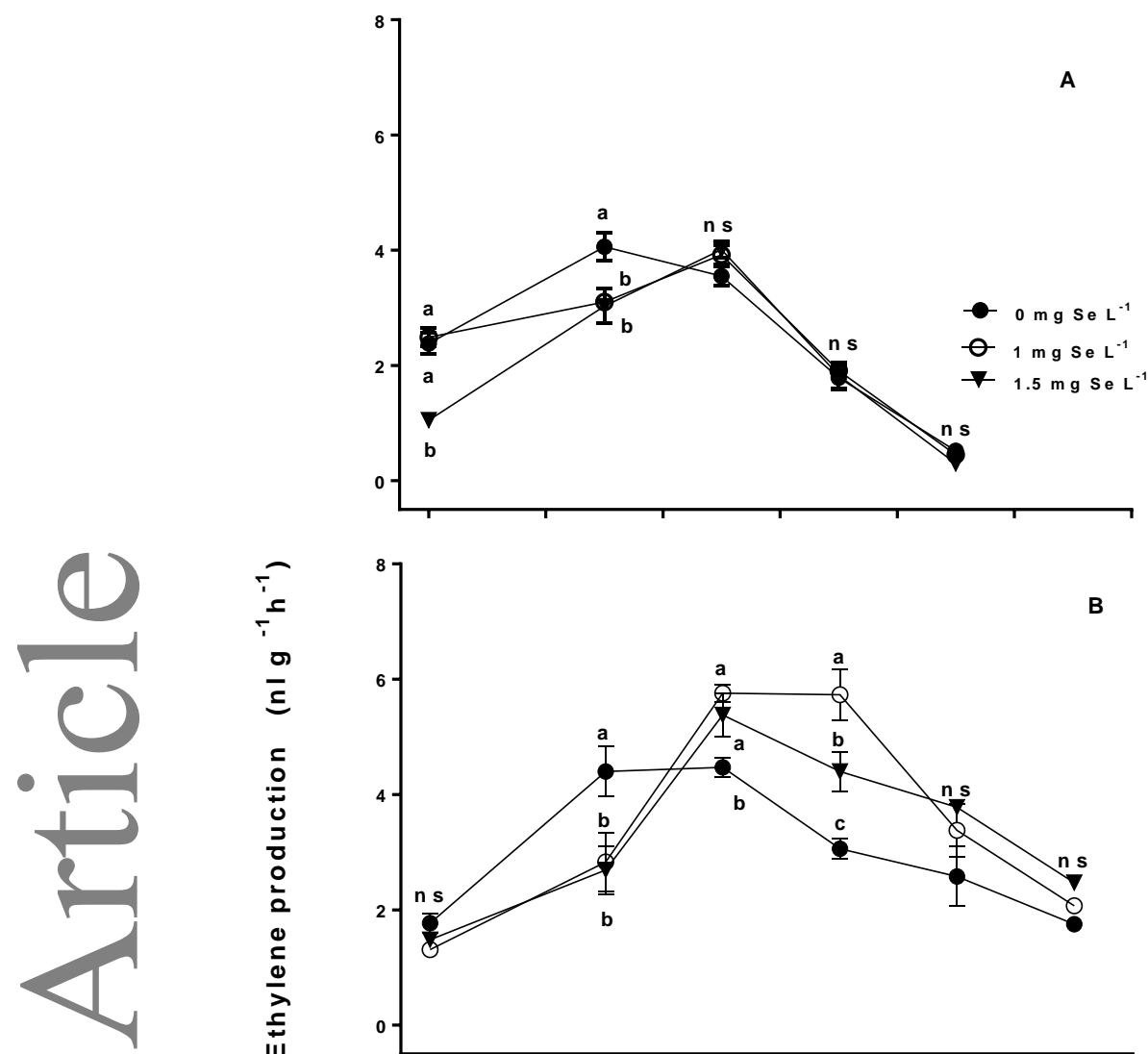

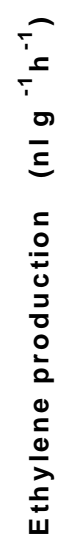
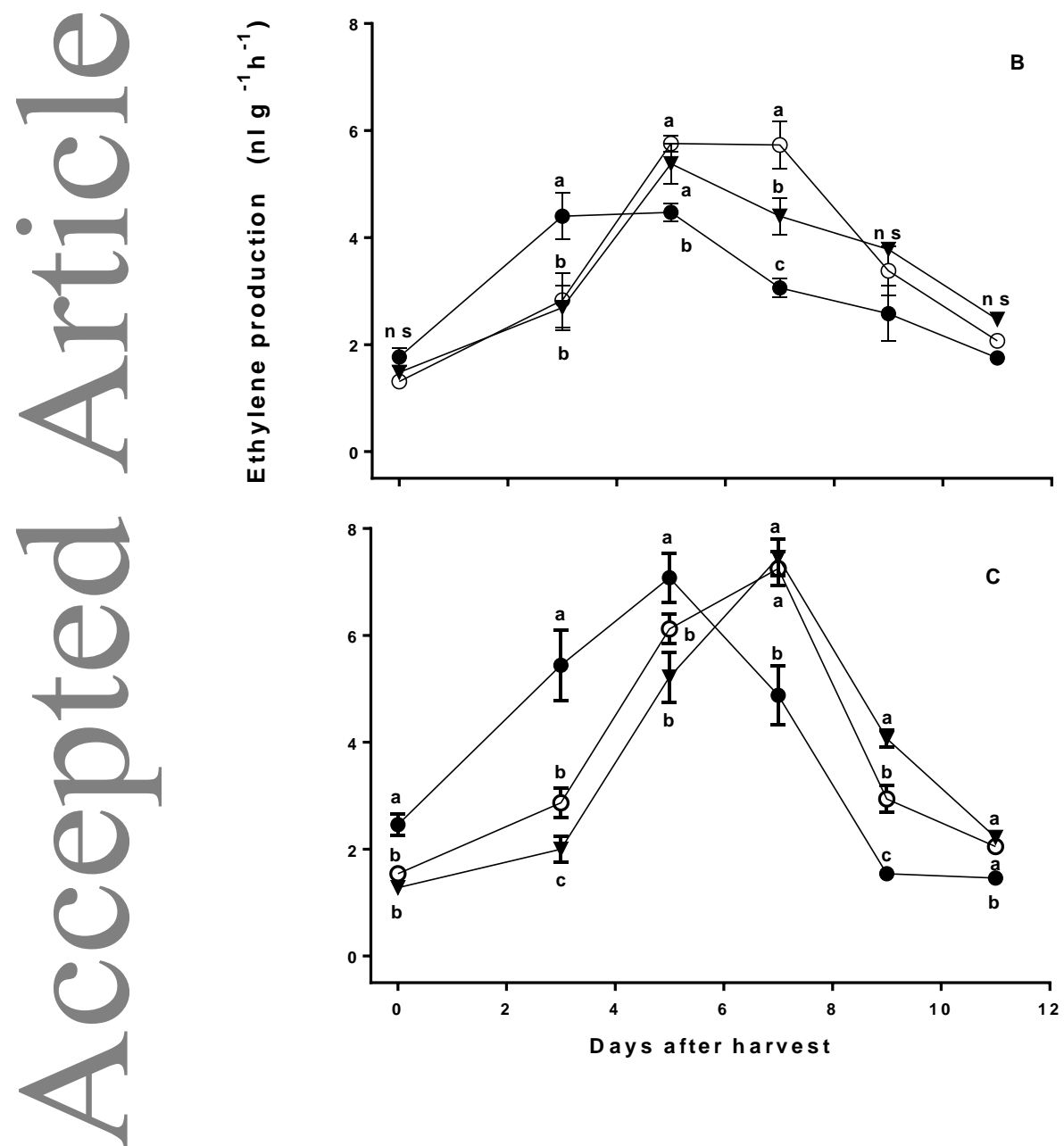

Figure 2. Ethylene production during post-harvest ripening in fruit of the first (A), second (B) and third (C) truss in tomato plants (cv. Red Bunch) grown in nutrient solution supplied with 0,1 and $1.5 \mathrm{mg} \mathrm{Se} \mathrm{L}^{-1}$. Data are means $\pm \mathrm{SE}(\mathrm{n}=4)$. Values with the same letter are not statistically different for $\mathrm{p} \leq 0.05 \%$; $\mathrm{ns}=$ not significant.

This article is protected by copyright. All rights reserved. 

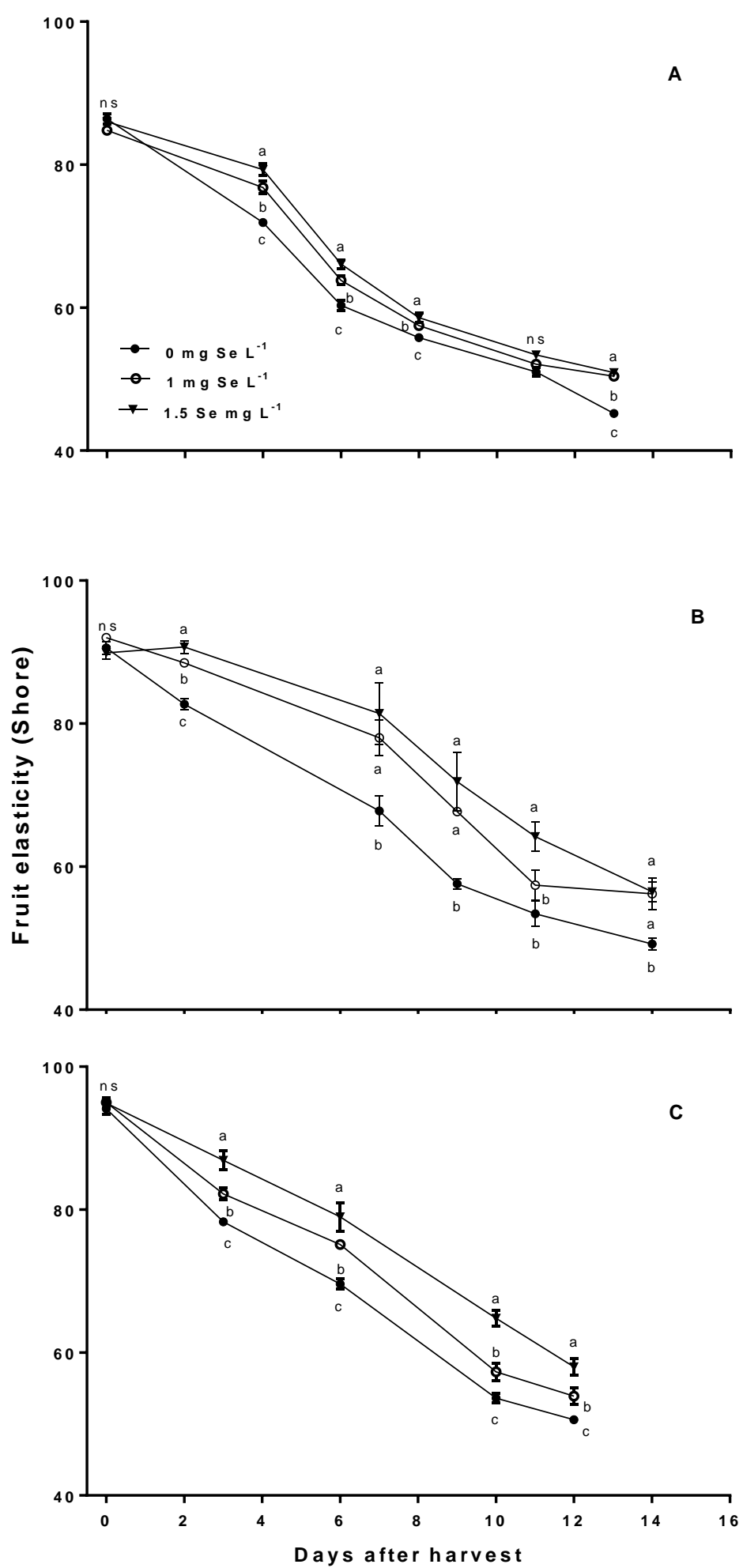

Figure 3. Fruit elasticity (Shore) during post-harvest ripening of fruit from the first (A), second (B) and third (C) truss of tomato plants (cv. Red Bunch) grown in nutrient solution supplied with 0, 1 and $1.5 \mathrm{mg} \mathrm{Se} \mathrm{L}^{-1}$. Data are means $\pm \mathrm{SE}(\mathrm{n}=6)$. Values with the same letter are not statistically different for $\mathrm{p} \leq 0.05 \%$; $\mathrm{ns}=$ not significant.

This article is protected by copyright. All rights reserved. 


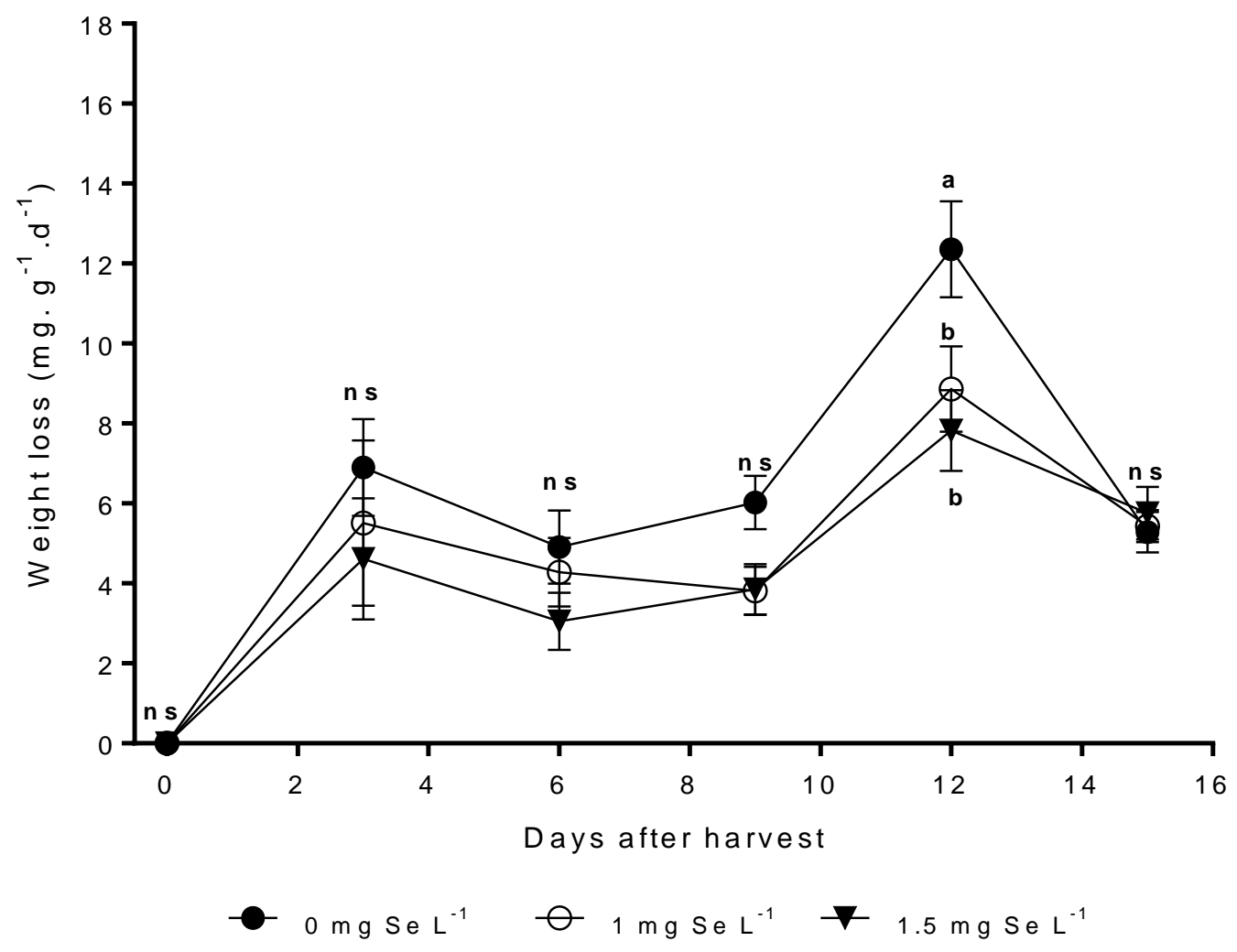

Figure 4. Post-harvest weight loss, expressed as $\mathrm{mg} / \mathrm{g}$ per day, in fruit of tomato plants (cv. Red Bunch) grown in nutrient solution supplied with 0,1 and $1.5 \mathrm{mg} \mathrm{Se} \mathrm{L}^{-1}$ and stored for 15 days.

Data are the means of the three trusses $\pm S E(n=18)$. Values with the same letter are not statistically different for $\mathrm{p} \leq 0.05 \%$; ns $=$ not significant.

This article is protected by copyright. All rights reserved. 
Table 1

Se concentration in red fruit of tomato plants (cv. Red Bunch) grown in nutrient solution supplied with 0,1 and $1.5 \mathrm{mg} \mathrm{Se} \mathrm{L}^{-1}$.

\begin{tabular}{|c|c|c|c|c|c|c|}
\hline \multirow{3}{*}{$\begin{array}{c}\mathrm{Se} \\
\left(\mathrm{mg} \mathrm{L}^{-1}\right)\end{array}$} & \multicolumn{3}{|c|}{ Se concentration $\left(\mathrm{mg} \mathrm{kg}^{-1} \mathrm{DW}\right)$} & \multicolumn{3}{|c|}{ Se concentration $\left(\mu \mathrm{g} \mathrm{kg}^{-1} \mathrm{FW}\right)$} \\
\hline & \multicolumn{3}{|c|}{ Truss } & \multicolumn{3}{|c|}{ Truss } \\
\hline & $1^{\text {st }}$ & $2^{\text {nd }}$ & $3^{\text {rd }}$ & $1^{\text {st }}$ & $2^{\text {nd }}$ & $3^{\text {rd }}$ \\
\hline 0 & $0 \pm 0^{\mathrm{c}}$ & $0 \pm 0^{\mathrm{c}}$ & $0 \pm 0^{\mathrm{c}}$ & $0 \pm 0^{\mathrm{c}}$ & $0 \pm 0^{\mathrm{c}}$ & $0 \pm 0^{\mathrm{c}}$ \\
\hline 1 & $2.76 \pm 0.18^{b}$ & $1.82 \pm 0.02^{b}$ & $0.94 \pm 0.05^{b}$ & $220 \pm 18^{b}$ & $146 \pm 3^{b}$ & $75 \pm 5^{b}$ \\
\hline 1.5 & $3.54 \pm 0.07^{\mathrm{a}}$ & $3.14 \pm 0.02^{\mathrm{a}}$ & $2.08 \pm 0.09^{\mathrm{a}}$ & $282 \pm 16^{\mathrm{a}}$ & $257 \pm 16^{\mathrm{a}}$ & $170 \pm 13^{\mathrm{a}}$ \\
\hline \multicolumn{7}{|c|}{ Significance } \\
\hline $\begin{array}{c}\mathrm{Se} \\
\left(\mathrm{mg} \mathrm{L}^{-1}\right)\end{array}$ & $* * *$ & $* * *$ & $* * *$ & $* * *$ & $* * *$ & $* * *$ \\
\hline
\end{tabular}

Values followed by different letters in the same column differ significantly at $5 \%$ level by the LSD test. Significance level: $* * * P \leq 0.001 ; * * P \leq 0.01 ; * P \leq 0.05 ;$ ns $=$ not significant.

This article is protected by copyright. All rights reserved. 


\section{Table 2}

Yield and qualitative characteristics of red fruit of tomato plants (cv. Red Bunch) grown in nutrient solution supplied with 0,1 and $1.5 \mathrm{mg} \mathrm{Se} \mathrm{L}^{-1}$. Data are the means of 3 replicates.

\begin{tabular}{lccccc}
\hline Parameters & & \multicolumn{3}{c}{ Se added $\left(\mathrm{mg} \mathrm{L}^{-1}\right)$} \\
\cline { 3 - 6 } & $\mathrm{g} \mathrm{FW} \mathrm{m}^{-2}$ & $2471 \pm 310$ & $2517 \pm 290$ & $2522 \pm 204$ & $\mathrm{~ns}$ \\
\hline Total yield & $\mathrm{g} \mathrm{FW} \mathrm{m}^{-2}$ & $1768 \pm 155$ & $1739 \pm 124$ & $1753 \pm 139$ & $\mathrm{~ns}$ \\
Commercial yield & $\%$ & $6.78 \pm 0.8$ & $6.72 \pm 0.72$ & $6.61 \pm 0.53$ & $\mathrm{~ns}$ \\
Solid content & ${ }^{\circ}$ Brix & $8.30 \pm 0.74$ & $8.11 \pm 0.86$ & $8.17 \pm 0.79$ & $\mathrm{~ns}$ \\
Solid soluble & & & & \\
content (SSC) & $\mathrm{g} \mathrm{citric} \mathrm{acid}^{\text {Titrable acidity }}$ & $0.70 \pm 0.06$ & $0.69 \pm 0.04$ & $0.71 \pm 0.08$ & $\mathrm{~ns}$ \\
Maturity index & $100 \mathrm{ml}^{-1}$ & 12 & 11.8 & 11.5 & $\mathrm{~ns}$ \\
Taste index & & 0.98 & 0.97 & 1.00 & $\mathrm{~ns}$ \\
\hline
\end{tabular}

Values followed by different letters in the same column differ significantly at 5\% level by the LSD test.

Significance level: $* * * P \leq 0.001 ; * * P \leq 0.01 ; * P \leq 0.05 ; n s=$ not significant.

This article is protected by copyright. All rights reserved. 
Table 3

Activity of antioxidant enzymes [Ascorbate peroxidase (APX), Catalase (CAT), Superoxide dismutase (SOD), Glutathione peroxidase (GPXs)] and lipid peroxidation expressed as malondialdehyde (MDA)

\begin{tabular}{|c|c|c|c|c|c|c|}
\hline \multirow{4}{*}{$\begin{array}{c}\mathrm{Se} \\
\left(\mathrm{mg} \mathrm{L}^{-1}\right)\end{array}$} & \multicolumn{6}{|c|}{ Respiration rate $\left(\mu \mathrm{mol} \mathrm{CO}_{2} \mathrm{~g}^{-1} \mathrm{~h}^{-1}\right)$} \\
\hline & \multicolumn{6}{|c|}{ Days after harvest } \\
\hline & \multicolumn{6}{|c|}{ First truss } \\
\hline & 0 & 3 & 5 & & 7 & 9 \\
\hline 0 & $2.70 \pm 0.36$ & $2.31 \pm 0.05$ & $2.40 \pm 0$ & .40 & $3.89 \pm 0.29$ & $2.36 \pm 0.17$ \\
\hline 1 & $2.66 \pm 0.37$ & $2.29 \pm 0.14$ & $2.36 \pm 0$ & .15 & $3.43 \pm 0.25$ & $2.22 \pm 0.20$ \\
\hline 1.5 & $2.23 \pm 0.35$ & $2.35 \pm 0.13$ & $2.40 \pm 0$ & .13 & $3.41 \pm 0.20$ & $2.26 \pm 0.12$ \\
\hline \multirow[t]{3}{*}{ Significance } & ns & ns & ns & & ns & ns \\
\hline & \multicolumn{6}{|c|}{ Second truss } \\
\hline & 0 & 3 & 5 & 7 & 9 & 11 \\
\hline 0 & $1.36 \pm 0.14$ & $1.15 \pm 0.11$ & $1.20 \pm 0.09$ & $1.52 \pm 0.12^{\mathrm{a}}$ & $2.13 \pm 0.14^{\mathrm{a}}$ & $1.12 \pm 0.10$ \\
\hline 1 & $1.22 \pm 0.10$ & $1.05 \pm 0.11$ & $1.17 \pm 0.07$ & $1.56 \pm 0.15^{\mathrm{a}}$ & $1.46 \pm 0.10^{\mathrm{b}}$ & $0.83 \pm 0.07$ \\
\hline 1.5 & $1.19 \pm 0.12$ & $1.16 \pm 0.08$ & $1.19 \pm 0.07$ & $1.25 \pm 0.10^{\mathrm{b}}$ & $1.66 \pm 0.13^{\mathrm{b}}$ & $0.90 \pm 0.09$ \\
\hline \multirow[t]{3}{*}{ Significance } & ns & ns & ns & $*$ & $*$ & ns \\
\hline & \multicolumn{6}{|c|}{ Third truss } \\
\hline & 0 & 3 & 5 & 7 & 9 & 11 \\
\hline 0 & $2.01 \pm 0.08$ & $2.05 \pm 0.12$ & $3.57 \pm 0.32^{\mathrm{a}}$ & $0.97 \pm 0.06^{\mathrm{b}}$ & $1.51 \pm 0.13$ & $0.94 \pm 0.07^{b}$ \\
\hline
\end{tabular}

content in red fruit of the first truss of tomato plants (cv. Red Bunch) grown in nutrient solution supplied

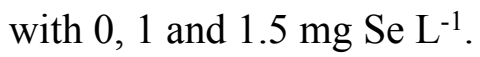

\begin{tabular}{lccccc}
\hline $\begin{array}{l}\text { Se added } \\
\mathrm{mg} \mathrm{L}^{-1}\end{array}$ & $\begin{array}{c}\text { APX activity } \\
\mu \text { moli AsA } \\
\mathrm{g}^{-1} \mathrm{FW} \mathrm{min}{ }^{-1}\end{array}$ & $\begin{array}{c}\text { CAT activity } \\
\mu \mathrm{mol} \mathrm{H}_{2} \mathrm{O}_{2} \\
\mathrm{~g}^{-1} \mathrm{FW} \mathrm{min}^{-1}\end{array}$ & $\begin{array}{c}\text { SOD activity } \\
\text { SOD Units } \\
\mathrm{g}^{-1} \mathrm{FW}\end{array}$ & $\begin{array}{c}\text { GPXs activity } \\
\mu \text { moli GSH } \\
\mathrm{g}^{-1} \mathrm{FW} \mathrm{min}^{-1}\end{array}$ & $\begin{array}{c}\text { MDA content } \\
\text { mmol MDA EQ } \\
\mathrm{g}^{-1} \mathrm{FW}\end{array}$ \\
\hline & & & & & \\
0 & $0.634 \pm 0.090^{\mathrm{a}}$ & $0.412 \pm 0.037^{\mathrm{a}}$ & $59.4 \pm 0.5^{\mathrm{c}}$ & $0.094 \pm 0.004$ & $156 \pm 6^{\mathrm{a}}$ \\
1 & $0.316 \pm 0.023^{\mathrm{b}}$ & $0.270 \pm 0.026^{\mathrm{b}}$ & $67.1 \pm 1.8^{\mathrm{b}}$ & $0.090 \pm 0.008$ & $138 \pm 4^{\mathrm{b}}$ \\
1.5 & $0.348 \pm 0.040^{\mathrm{b}}$ & $0.279 \pm 0.016^{\mathrm{b}}$ & $83.6 \pm 1.6^{\mathrm{a}}$ & $0.089 \pm 0.009$ & $126 \pm 4^{\mathrm{b}}$ \\
\hline Significance & $* *$ & $* *$ & $* * *$ & $\mathrm{~ns}$ & $*$ \\
\hline
\end{tabular}

Values followed by different letters in the same column differ significantly at $5 \%$ level by the LSD test. Significance level: $* * * P \leq 0.001 ; * * P \leq 0.01 ; * P \leq 0.05 ;$ ns $=$ not significant.

Table 4. Respiration rate during post-harvest ripening in fruit of first, second and third truss of tomato plants (cv. Red Bunch) subjected to different Se treatments. Values are means with standard errors $(n=4)$.

This article is protected by copyright. All rights reserved. 


\begin{tabular}{|c|c|c|c|c|c|c|}
\hline $\begin{array}{c}1 \\
1.5\end{array}$ & $\begin{array}{l}1.81 \pm 0.20 \\
1.92 \pm 0.05\end{array}$ & $\begin{array}{l}1.89 \pm 0.12 \\
1.63 \pm 0.14\end{array}$ & $\begin{array}{l}2.78 \pm 0.09^{\mathrm{b}} \\
2.78 \pm 0.22^{\mathrm{b}}\end{array}$ & $\begin{array}{l}1.49 \pm 0.08^{\mathrm{a}} \\
111 \pm 0.09^{\mathrm{b}}\end{array}$ & $\begin{array}{l}1.33 \pm 0.10 \\
1.57 \pm 0.12\end{array}$ & $\begin{array}{l}1.38 \pm 0.16^{\mathrm{a}} \\
1.57 \pm 0.14^{\mathrm{a}}\end{array}$ \\
\hline & & & & & & \\
\hline \multirow{2}{*}{$\begin{array}{c}\text { Significance } \\
\text { Se }\end{array}$} & ns & $\mathrm{ns}$ & \multicolumn{2}{|c|}{ * Days after harvést } & $\mathrm{ns}$ & * \\
\hline & \multicolumn{6}{|c|}{ Glueose (mg g-1 $\mathrm{FW})$} \\
\hline$\left(\mathrm{mg} \mathrm{L} \mathrm{L}^{-1}\right)$ & \multicolumn{2}{|l|}{0} & 4 & 8 & & 12 \\
\hline 0 & \multicolumn{2}{|c|}{$13.6 \pm 1.3$} & $16.0 \pm 0.8^{\mathrm{a}}$ & $17.2 \pm 0.5^{\mathrm{a}}$ & \multicolumn{2}{|r|}{$17.1 \pm 0.3$} \\
\hline 1 & \multicolumn{2}{|c|}{$13.4 \pm 1.2$} & $14.3 \pm 0.6^{b}$ & $15.5 \pm 0.5^{\mathrm{b}}$ & \multicolumn{2}{|r|}{$16.6 \pm 0.6$} \\
\hline 1.5 & \multicolumn{2}{|c|}{$12.5 \pm 0.8$} & $14.3 \pm 0.6^{\mathrm{b}}$ & $15.1 \pm 0.4^{\mathrm{b}}$ & & $17.2 \pm 0.8$ \\
\hline \multirow[t]{3}{*}{ Significance } & \multicolumn{2}{|l|}{ ns } & $*$ & $*$ & \multicolumn{2}{|r|}{ ns } \\
\hline & \multicolumn{6}{|c|}{ Fructose $\left(\mathrm{mg} \mathrm{g}^{-1} \mathrm{FW}\right)$} \\
\hline & \multicolumn{2}{|l|}{0} & 4 & 8 & \multicolumn{2}{|r|}{12} \\
\hline 0 & \multicolumn{2}{|c|}{$14.6 \pm 1.2$} & $18.9 \pm 0.7^{\mathrm{a}}$ & $20.2 \pm 0.7^{\mathrm{a}}$ & \multicolumn{2}{|r|}{$20.6 \pm 0.6$} \\
\hline 1 & \multicolumn{2}{|c|}{$13.9 \pm 1.3$} & $16.9 \pm 0.6^{b}$ & $18.4 \pm 0.2^{b}$ & \multicolumn{2}{|r|}{$20.2 \pm 1.1$} \\
\hline 1.5 & \multicolumn{2}{|c|}{$13.5 \pm 0.5$} & $16.8 \pm 0.2^{b}$ & $17.4 \pm 0.4^{b}$ & \multicolumn{2}{|r|}{$19.8 \pm 0.7$} \\
\hline Significance & \multicolumn{2}{|l|}{$\mathrm{ns}$} & $*$ & $* *$ & \multicolumn{2}{|r|}{ ns } \\
\hline
\end{tabular}

Values followed by different letters in the same column differ significantly at 5\% level by the LSD test. Significance level: $* * * P \leq 0.001 ; * * P \leq 0.01 ; * P \leq 0.05 ;$ ns $=$ not significant.

Table 5. Non-structural carbohydrates concentration in fruit of tomato plants (cv. Red Bunch) subjected to different Se treatments. Values are means with standard errors $(n=4)$.

Values followed by different letters in the same column differ significantly at $5 \%$ level by the LSD test Significance level: $* * * P \leq 0.001 ; * * P \leq 0.01 ; * P \leq 0.05$; ns $=$ not significant.

This article is protected by copyright. All rights reserved. 


\begin{tabular}{|c|c|c|c|c|}
\hline \multirow{3}{*}{$\begin{array}{c}\mathrm{Se} \\
\left(\mathrm{mg} \mathrm{L}^{-1}\right)\end{array}$} & \multicolumn{4}{|c|}{ Days after harvest } \\
\hline & \multicolumn{4}{|c|}{ Lycopene $\left(\mu \mathrm{g} \mathrm{g}^{-1} \mathrm{FW}\right)$} \\
\hline & 0 & 4 & 8 & 12 \\
\hline 0 & $2.97 \pm 0.09$ & $84.8 \pm 4.43^{\mathrm{a}}$ & $174.4 \pm 6.23^{\mathrm{a}}$ & $195.5 \pm 18.58$ \\
\hline 1 & $3.25 \pm 0.26$ & $48.6 \pm 6.03^{b}$ & $110.8 \pm 8.45^{b}$ & $210.3 \pm 18.17$ \\
\hline 1.5 & $3.38 \pm 0.23$ & $46.3 \pm 4.17^{b}$ & $90.3 \pm 7.96^{\mathrm{c}}$ & $199.7 \pm 4.90$ \\
\hline \multirow[t]{3}{*}{ Significance } & ns & $* *$ & $* * *$ & ns \\
\hline & \multicolumn{4}{|c|}{$\beta$-carotene $\left(\mu \mathrm{g} \mathrm{g}^{-1} \mathrm{FW}\right)$} \\
\hline & 0 & 4 & 8 & 12 \\
\hline 0 & $3.59 \pm 0.30$ & $5.79 \pm 0.30^{\mathrm{a}}$ & $6.67 \pm 0.34^{\mathrm{a}}$ & $6.99 \pm 0.57$ \\
\hline 1 & $3.49 \pm 0.28$ & $4.62 \pm 0.12^{b}$ & $5.43 \pm 0.19^{b}$ & $6.89 \pm 0.53$ \\
\hline 1.5 & $3.63 \pm 0.19$ & $4.05 \pm 0.20^{\mathrm{c}}$ & $4.68 \pm 0.19^{c}$ & $6.50 \pm 0.23$ \\
\hline
\end{tabular}

Table 6. Lycopene, $\beta$-carotene, chlorophyll a and chlorophyll b concentration in fruit of tomato plants (cv. Red Bunch) subjected to different Se treatments during post-harvest.

This article is protected by copyright. All rights reserved. 


\begin{tabular}{|c|c|c|c|c|}
\hline Significance & ns & $* * *$ & $* *$ & ns \\
\hline & \multicolumn{4}{|c|}{ Chlorophyll a $\left(\mu \mathrm{g} \mathrm{g}^{-1} \mathrm{FW}\right)$} \\
\hline & 0 & 4 & 8 & 12 \\
\hline 0 & $1.72 \pm 0.008$ & $1.29 \pm 0.12$ & $0 \pm 0^{\mathrm{b}}$ & $0 \pm 0$ \\
\hline 1 & $1.59 \pm 0.11$ & $1.50 \pm 0.08$ & $1.03 \pm 0.03^{\mathrm{a}}$ & $0 \pm 0$ \\
\hline 1.5 & $1.76 \pm 0.06$ & $1.41 \pm 0.08$ & $0.93 \pm 0.03^{\mathrm{a}}$ & $0 \pm 0$ \\
\hline \multirow[t]{3}{*}{ Significance } & ns & ns & $* * *$ & ns \\
\hline & \multicolumn{4}{|c|}{ Chlorophyll b ( $\left.\mu \mathrm{g} \mathrm{g}^{-1} \mathrm{FW}\right)$} \\
\hline & 0 & 4 & 8 & 12 \\
\hline 0 & $1.57 \pm 0.02$ & $0.64 \pm 0.05$ & $0.00 \pm 0.00^{\mathrm{b}}$ & $0 \pm 0$ \\
\hline 1 & $1.40 \pm 0.11$ & $0.93 \pm 0.08$ & $0.53 \pm 0.02^{\mathrm{a}}$ & $0 \pm 0$ \\
\hline 1.5 & $1.56 \pm 0.03$ & $0.79 \pm 0.09$ & $0.48 \pm 0.01^{\mathrm{a}}$ & $0 \pm 0$ \\
\hline Significance & ns & ns & $* * *$ & ns \\
\hline
\end{tabular}

Values followed by different letters in the same column differ significantly at 5\% level by the LSD test. Significance level: $* * * P \leq 0.001 ; * * P \leq 0.01 ; * P \leq 0.05 ;$ ns $=$ not significant.

This article is protected by copyright. All rights reserved. 